\title{
Author index volume 16 (1998)
}

(The issue number is given in front of the page numbers)

Al-Ansari, H., see Alqudsi-Ghabra, T.

Agada, J., Profiling librarians with the Myers-Briggs Type Indicator: studies in self selection and type stability

(2) $145-152$

(1) $57-68$

Alqudsi-Ghabra, T. and Al-Ansari, H., Education for Library and Information Science at Kuwait University (Short communication) (2) 145-152

Bawden, D., see Urquhart, C.

(1) $69-81$

Baxter, G., see Marcella, R.

(2) $107-130$

Campbell, F., see Farmer, J.

(2) $95-106$

Chaudhry, A.S., see Rehman, S.

(1) $9-28$

(4) $295-314$

Cochrane, C., The attitudes of undergraduate Information Management students to seminars: a qualitative and a quantitative analysis

(4) $315-331$

Farmer, J. and Campbell, F., Identifying the transferable skills of information professionals through mentoring

(2) $95-106$

Goulding, A. and Cleeve, M., Breaking down the barriers: the place of gender equity in the ILS curriculum

(4) $295-314$

Haider, S.J., Educating future librarians in Pakistan - a library educator's perspective

(1) $29-44$

Hornby, S., see Urquhart, C.

(1) $69-81$

Jager, K. de and Nassimbeni, M., Roadmaps for the Highway: the evaluation of an information literacy training programme for South African students

(2) $131-143$

Jiménez-Contreras, E. and Pulgarín-Guerrero, A., BibliometricsInformetrics and other quantitative subjects in Library and Information Science curricula in Spain

(4) $341-355$

Johnson, I.M., Guest-editorial: Peering into the mist and struggling through it - the education and training of the future information professional
(1) $\quad 1-8$ 
Johnson, I.M., UNESCO and human resource development for the 'Information Society'

(3) $237-242$

Karim, N.S.A., see Rheman, S.

Kennedy, J., Education for collection management: ending before

(1) $\quad 9-28$ it ever really started, or only just beginning?

(1) $45-56$

Lim, E., Human resource development for information societies an Asian perspective

(3) $219-236$

Nassimbeni, M., see Jager, K. de

(2) $131-143$

Main, L., Web-based virtual classrooms: a model for LIS education

(4) $333-340$

Marcella, R. and Baxter, G., A career progression survey of graduates of the Postgraduate Diploma/MSc in Information Analysis

(2) $107-130$

Moore, N., The future demand for information professionals in Europe

(3) $191-208$

Prudtikul, S., A survey of the institutions in Asia and the Pacific offering library and information studies through distance learning

(3) $209-218$

Pulgarín-Guerrero, A., see Jiménez-Contreras, E.

(4) $341-355$

Rehman, S., Karim, N.S.A. and Chaudhry, A.S., Differentiated competencies for graduate and undergraduate levels: needed transformation of the information study programs

Rogers, T., see Urquhart, C.

(1) $\quad 9-28$

(1) $69-81$

Stueart, R.D., Preparing Information Professionals for the Next Century

Urquhart, C., Hornby, S., Rogers, T. and Bawden, D., The health information practitioner as learner and educator

(1) $69-81$

Wormell, I., Establishment of a LIS research and education network in the Republic of South Africa - A project with roots in the FID/ET committee work (Short Communication)

(3) $253-254$ 